Research Article

\title{
Cross-Cultural Adaptation and Validation of the Korean Version of the Dundee Ready Education Environment Measure (DREEM)
}

\author{
Hyunho Kim, ${ }^{1}$ Pyeongjin Jeon, ${ }^{2}$ Seungju Kim, ${ }^{3}$ Jiseong Hong, ${ }^{4}$ and Yeonseok Kang $\mathbb{D}^{5,6}$ \\ ${ }^{1} 7$ Days Inc., Seoul, Republic of Korea \\ ${ }^{2}$ Boneline Korean Medicine Clinic, Seoul, Republic of Korea \\ ${ }^{3}$ Sarangin Korean Medicine Clinic, Ansan, Republic of Korea \\ ${ }^{4}$ Research Center of Korean Traditional Medicine, Wonkwang University, Iksan, Republic of Korea \\ ${ }^{5}$ Department of Medical History, College of Korean Medicine, Wonkwang University, Iksan, Republic of Korea \\ ${ }^{6}$ Institute of Korean Medicine Education and Evaluation, Seoul, Republic of Korea \\ Correspondence should be addressed to Yeonseok Kang; yeonkang@wku.ac.kr
}

Received 21 January 2021; Revised 30 June 2021; Accepted 3 August 2021; Published 17 August 2021

Academic Editor: Jose C Adsuar

Copyright (C) 2021 Hyunho Kim et al. This is an open access article distributed under the Creative Commons Attribution License, which permits unrestricted use, distribution, and reproduction in any medium, provided the original work is properly cited.

Internationally, Dundee Ready Education Environment Measure (DREEM) is being used to evaluate and compare students' awareness regarding medical education environment. This study aimed to adapt DREEM into Korean, to evaluate the reliability and validity, and to compare its structure to the original DREEM structure. The DREEM was translated using 6 steps which were suggested in cross-cultural adaptation protocols: translation, synthesis, back translation, expert committee review, pilot test, and psychometric study $(N=451)$. We performed confirmatory factor analysis including basic analysis. For evaluating the original model's goodness of fit with the acquired dataset, model fit indices and construct validity were discussed. The Korean version was completed upon through cross-cultural adaptation protocols. Statistical analysis with 451 data sets showed that the root mean square error of approximation $=0.06$, goodness-offit index $=0.75$, and Tucker-Lewis index $=0.73$. Almost construct reliabilities were all over 0.707 . Except for just one pair, all squares of correlation coefficients were greater than the corresponding average variance extracted. In conclusion, we developed the Korean version of DREEM. Although the original 5-factor structure was acceptable, low convergent and discriminant validity indices suggested that further studies for the Korean environment are necessary for the respecified or modified factor structures.

\section{Introduction}

Medical education's principal aim is to produce medical doctors who will be ready to serve the fundamental purposes of medicine: curing disease and participating in all social aspects related to medicine and healthcare [1]. Therefore, many countries have tried to build effective and meaningful medical education systems. Furthermore, educator-centered and nonintegrated education systems have been transformed into student-centered and integrated learning systems [2-7]. Medical education is composed of several factors, of which educational environment is one of the most important [8]. Educational environment is a very complex area that, in a comprehensive sense, encompasses the physical location, cultural curriculum, educational facilities, and methods of education $[4,9]$. Educational environments are as important as expertise delivery in medical education [8]. Educational environments contribute to students' achievements, satisfaction, healthy competition, independence, self-confidence, critical thinking, aspirations, and so on $[4,10-14]$. Accordingly, it is very important to provide an appropriate environment for facilitating effective medical education [15].

Therefore, educators and policy makers should consider the educational environments in order to improve education quality, and researchers have developed various tools for evaluating educational environments $[9,16,17]$. Pace and Stern developed the College Characteristics Index (CCI) to 
understand students' perceptions of educational environment [18]. Hutchins developed the Medical School Environment Inventory (MSEI) in order to study medical colleges. Fanslow specifically developed the College Environment Inventory for Women (CEIW) for a study on female college students $[19,20]$. Furthermore, other tools include the Classroom Environment Scales (CES), the Inventory of College Characteristics (ICCS), the Learning Environment Inventory (LEI), the College and University Environment Inventory (CUCEI), the Institutional Goals Index (IGI), and the Institutional Functioning Inventory (IFI) [21].

Recently, the Dundee Ready Education Environment Measure (DREEM) has been widely used internationally to evaluate students' perceptions regarding the various aspects of educational environments $[22,23]$. Dr. Sue Roff of the University of Dundee in England developed DREEM in 1997 using the Delphi method [21]. Its questionnaire items were translated and used in at least 20 countries [22]. Its validity and reliability were verified $[21,22]$. But some studies indicated poor data on the five-factor structure and construct validity. They recommended the need for further research and improvement [24-36].

In Korea, a DREEM-based survey was distributed across 40 medical colleges nationwide in 2013 [37] and in one college of Korean medicine in 2015 [38]. Because the DREEM was originally developed in English, this international tool includes some problems associated with language issues and multicultural populations $[39,40]$. To avoid the ambiguities and inconsistencies with regard to meaning on word in each version, a strict translation process should be applied for considering the equivalence between the original language version and the target language version. Crosscultural adaptation is a normative methodology used by researchers in order to consider the differences in languages and cultural backgrounds [41].

In this study, we conducted a series of cross-cultural adaptation processes to develop a Korean version of DREEM based on the English version. We also performed a psychometric study with confirmative factor analysis to identify whether the latent variable structure of the original version could be applied to Korean medicine students.

\section{Methods}

2.1. The Dundee Ready Educational Environment Measure Questionnaire. DREEM has fifty items and a 5-factor structure: SPL (students' perception of learning [12 items]), SPT (students' perception of teachers [11 items]), SAS (students' academic self-perception [8 items]), SPA (students' perception of atmosphere [12 items]), and SSS (students' social self-perception [7 items]).

A bipolar 5-point Likert scale with a neutral response is applied (0: strongly disagree; 1 : disagree; 2 : neither agree nor disagree; 3 : agree; 4 : strongly agree) to the 50 items. Among the fifty items, nine items (item $4,8,9,17,25,35,39,48$, and 50) are negative sentences; therefore, they should be reversely coded when scoring and analysis are performed. High scores indicate a positive evaluation regarding the education environment. The developers provided an interpretation guideline for each item or each factor. According to that guideline, items or factors with a score equal to or greater than 3.5 indicate a very positively evaluated area; items or factors with a score between 2 and 3 indicate a positively evaluated area but, however, require some efforts to enhance education environment, and items or factors with a score equal to or less than 2.0 indicate that have to demand attention to education environment [42]. The DREEM questionnaire enables researchers to quantitatively assess students' perceptions of the educational environment. It also makes it feasible to compare results across different institutions, various curriculums, and different survey researches [17].

2.2. Cross-Cultural Adaptation Process. Wherever the crosscultural adaptation guideline is presented, there is a slight difference in process; however, in general, a serial process of translation, back translation, review, and pretesting is performed [39-41, 43-45]. The World Health Organization (WHO) guidelines also recommend a serial process of forward translation, expert panel back translation, pretesting, cognitive interviewing, and fixing the final version [46]. In this study, we referred to the adaptation guidelines written by Beaton [39] as well as Sousa and Rojjanasrirat's [40] six stages.

Before starting this study, the authors informed Dr. Sue Roff, the original developer of DREEM, about this crosscultural adaptation and received her permission along with her kind and helpful advice via e-mail. Figure 1 depicts the overall process underlying the cross-cultural adaptation of DREEM.

During the first stage, two translators independently translated the English DREEM items into Korean. Their mother tongue was Korean, but they could speak English fluently. We provided this research's aims and advance information to translator 1 (T1), while translator 2 (T2) was provided with no information regarding this study. During stage 2, we synthesized the two products obtained from T1 and $\mathrm{T} 2$. After we showed the synthesized version to $\mathrm{T} 1$ and T2, we received feedback from the two translators and revised the manuscript (early Korean version). During stage 3, two other translators independently translated the early Korean version produced in stage 2 into English. The two back-translators (BT1 and BT2) were not provided with any information on the original version of DREEM and the medical education system. During stage 4 , we organized an expert committee where we developed the prefinal Korean version of DREEM after considering and analyzing all the products obtained from $\mathrm{T} 1, \mathrm{~T} 2, \mathrm{BT} 1$, and $\mathrm{BT} 2$. A total of eight experts participated in the committee: one survey research methodologist, one healthcare professional, one language professional, one education professional, and four translators (T1, T2, BT1, and BT2). The first two members of the committee, and two translators (T1 and T2), were Korean medicine doctors who worked in the college of Korean medicine. Throughout stage 4 , the committee members focused on semantic equivalence, idiomatic equivalence, 


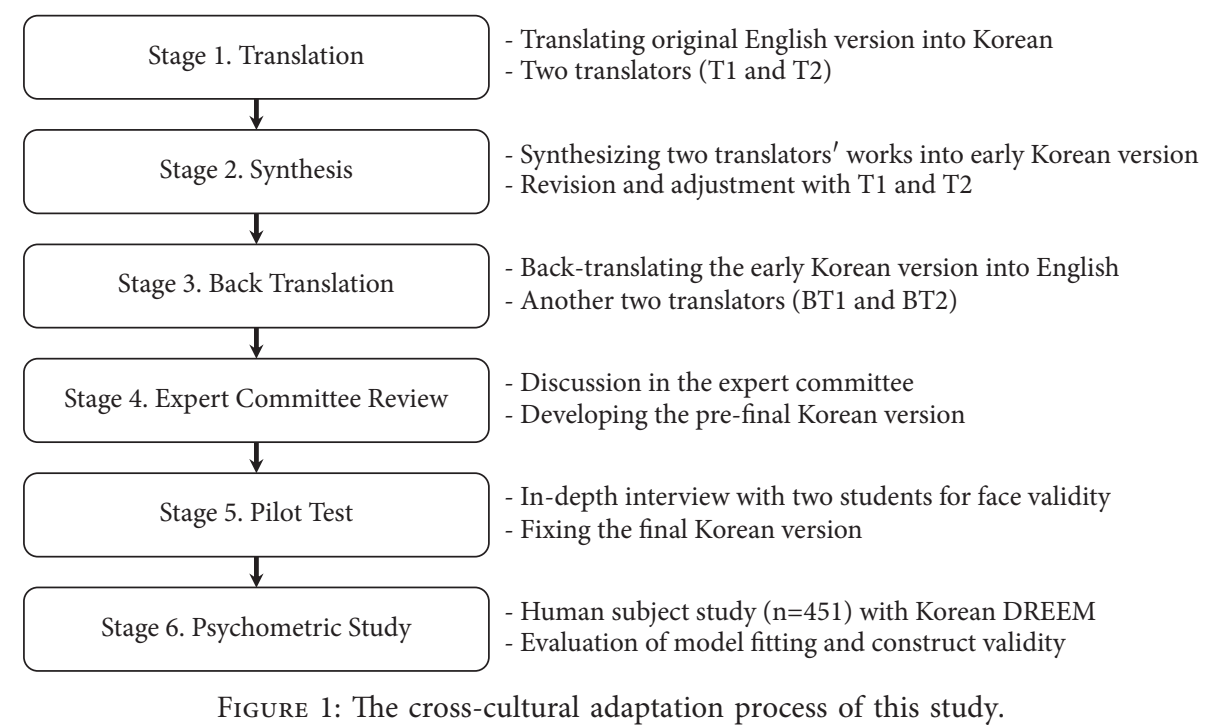

experiential equivalence, and conceptual equivalence in order to maintain the equivalence between the original English version and the new Korean version [39, 43]. Dr. Sue Roff's answers and advice were very helpful during this stage. We were able to develop the prefinal Korean version of DREEM in stage 4 . During the next stage, we conducted an in-depth interview with two students to confirm the clarity of the items. They provided advice from a student's point of view, and almost no changes were made in prefinal version. Consequently, the Korean version of DREEM was finalized. During the final stage, we performed a psychometric study using the Korean version of DREEM. This was followed by statistical analysis including descriptive study and confirmatory factor analysis.

2.3. Psychometric Testing and Statistical Analysis. After completing the cross-cultural adaptation, we performed a human subject research using the newly developed Korean version of DREEM. A survey was administered to secondyear to sixth-year students in two universities. The online survey platform Survey Monkey (Survey Monkey, CA, USA) was used for collecting the responses. A total of 218 students and 233 students from two universities, respectively, voluntarily participated in the online survey. This human subject research was approved by the Institutional Review Board of Kyung Hee University Korean Medicine Hospital (KOMCIRB-161020-HR-059).

We performed descriptive statistical methods in order to summarize the basic characteristics and responses to the survey and confirmatory factor analysis to compare the latent variable structure of this population with the original structure and previous studies. For evaluating the goodness of fit of the original model using the acquired dataset, several model fit indices were calculated and discussed: goodnessof-fit index (GFI), adjusted goodness-of-fit index (AGFI), root mean square error of approximation (RMSEA), normed fit index (NFI), Tucker-Lewis index (TLI), and comparative fit index (CFI). With these model fit indices, we investigated the factor loading of each item, the construct reliability (CR) for the convergent validity, and the average variance extracted (AVE) for the discriminant validity. We used Microsoft Excel Office 365 (Microsoft, Redmond, WA, USA) for performing the descriptive statistics and R 3.6.1. (R Core Team, Vienna, Austria) and R packages "sem" for performing confirmatory factor analysis.

\section{Results}

3.1. Cross-Cultural Adaptation of the DREEM Questionnaire. Table 1 presents the Korean version of DREEM, which was developed using the cross-cultural adaptation process.

\subsection{Psychometric Test Results}

3.2.1. Demographic Statistics and the Overall and Subgroup Analysis of the Psychometric Test. A total of 451 students from two Korean medicine colleges voluntarily responded to the survey inquiry. All items were answered, and there was no missing data. Tables 2 and 3 present the overall results and subgroup analysis results, respectively. The descriptive statistics provided in the tables show that over half of the items were identified as being problematic, with scores equal to or less than 2.0. The students responded negatively to many items in general. Almost no differences were found between colleges and genders and among school years.

3.2.2. Confirmatory Factor Analysis of the Psychometric Test. Figure 2 presents the result of the confirmatory factor analysis of the 5-factor model based on the original DREEM questionnaire with the acquired dataset. Factor loadings and construct reliabilities (CRs) for evaluating the convergent validity are also presented in the same figure. The indices for model fit are as follows: $\mathrm{GFI}=0.75, \mathrm{AGFI}=0.73, \mathrm{NFI}=0.65$, $\mathrm{TLI}=0.73, \mathrm{CFI}=0.74$, and $\mathrm{RMSEA}=0.06$. Table 4 shows the correlation coefficients and the average variance extracted (AVE) for evaluating the discriminant validity. 
TABLE 1: The final Korean version of DREEM developed in this study.

\begin{tabular}{|c|c|c|c|}
\hline Item & Subscale & Original version (Sue Roff, 1997) & Korean version (this study) \\
\hline 1 & SPL & I am encouraged to participate in class & 수업시간에 적극적으로 참여하도록 독려 받는다 \\
\hline 2 & SPT & The teachers are knowledgeable & 교수들은 풍부한 지식을 갖고 있다 \\
\hline 3 & SSS & There is a good support system for students who get stressed & $\begin{array}{c}\text { 스트레스를 받는 학생들을 위한 지원체계가 잘 갖 } \\
\text { 춰져 있다 }\end{array}$ \\
\hline 4 & SSS & njoy this course & 나는 너무 피로해서 학교생활을 즐기기 어렵다 \\
\hline 5 & SAS & $\begin{array}{l}\text { Learning strategies which worked for me before continue to work } \\
\text { for me now }\end{array}$ & $\begin{array}{c}\text { 이전에 효과가 있었던 공부법이 현재에도 효과가 } \\
\text { 있다 }\end{array}$ \\
\hline 6 & SPT & The teachers are patient with patients & 교수들이 환자 중심적으로 접근하는 편이다 \\
\hline 7 & & & 수업은 흥미를 불러일으켜 주는 편이다 \\
\hline 8 & & idents & 교수들이 학생들을 비하한다 \\
\hline 9 & & uthoritarian & 교수들이 권위적이다 \\
\hline 10 & AS & I am con & 나는 올해 진급할 것을 확신한다 \\
\hline 11 & SPA & The atmosphere is & 병원실습 분위기는 편안하다 \\
\hline 12 & SPA & This school is well timetabled & $\begin{array}{c}\text { 우리 학교의 학사일정, 교육과정, 시간표는 잘 짜 } \\
\text { 여 있다 }\end{array}$ \\
\hline 13 & SPL & The teac & 수업은 학생 중심적이다 \\
\hline 14 & & & 나는 학교생활이 거의 지루하지 않다 \\
\hline 15 & $\mathrm{~S}$ & & 나는 학교에 좋은 친구들이 있다 \\
\hline 16 & $\mathrm{~S}$ & The teaching is sufficiently conc & 수업은 나의 역량을 계발하는데 도움이 된다 \\
\hline 17 & A & Cheating is a prob & 수업이나 시험에서 부정행위가 문제되고 있다 \\
\hline 18 & & The teachers have good $\mathrm{c}$ & 교수들은 환자들과 의사소통을 잘 하는 편이다 \\
\hline 19 & $\mathrm{~S}$ & is orod & 학교 내에서의 대인관계는 원만하다 \\
\hline 20 & SPL & The $t$ & 수업의 요점이 명확하다 \\
\hline 21 & SAS & I feel I am being well prepared for my profession & $\begin{array}{c}\text { 나는 의료인으로서의 전문성이 잘 준비되고 있다 } \\
\text { 고 느낀다 }\end{array}$ \\
\hline 22 & SPL & The teaching is $\mathrm{s}$ & 수업은 자신감을 키우는데 도움이 된다 \\
\hline 23 & & The atmosp & 강의식 수업 분위기는 편안하다 \\
\hline 24 & & & 수업시간은 잘 활용된다 \\
\hline 25 & S & The teac & $\begin{array}{c}\text { 수업이 지식 전달에 치우쳐 있다 } \\
\text { 자녀에 고브하 거드의 }\end{array}$ \\
\hline 26 & SAS & Last year's work $\mathrm{h}$ & $\begin{array}{c}\text { 년에 공부한 것들이 올해 공부하는데 큰 도움이 } \\
\text { 되었다 }\end{array}$ \\
\hline 27 & $S$ & I & 나는 필요한 모든 것을 암기 할 수 있다 \\
\hline 28 & & & 나는 거의 외롭지 않다 \\
\hline 29 & & e & 교수들은 학생들에게 적절한 피드백을 준다 \\
\hline 30 & & here are opport & 대인관계능력을 계발할 수 있는 기회가 있다 \\
\hline 31 & & I have learne & 의료인으로서의 공감능력을 많이 습득해 왔다 \\
\hline 32 & SPT & The teachers provide con & 교수들은 발전적인 방향으로 격려한다 \\
\hline 33 & A & $\mathrm{I}$ & 다 \\
\hline 34 & SPA & $\mathrm{T}$ & 소그룹수업/조별활동의 분위기가 편안하다 \\
\hline 35 & & & 학교를 다니면서 실망스러운 경험을 하곤 한다 \\
\hline 36 & & $\mathrm{I}+\mathrm{x}^{2}$ & 나는 집중을 잘 할 수 있다 \\
\hline 37 & & les & 교수들은 명확한 예시를 활용한다 \\
\hline 38 & & I am clear at & 나는 각 수업의 학습목표들을 명확히 이해한다 \\
\hline 39 & & & 교수들이 수업 중에 화를 낸다 \\
\hline 40 & & & 교수들은 수업준비를 잘 한다 \\
\hline 41 & S & y problem-solving skills are being well deve & 나의 문제 해결 능력이 향상되고 있다 \\
\hline 42 & SPA & The enjoyment ou & 20 \\
\hline 43 & & The & 학교 분위기가 학습의욕을 향상시킨다 \\
\hline 44 & & The teach & 여받는다 \\
\hline 45 & SAS & Much of what I hav & 편이다 \\
\hline 46 & & & 학생 편의시설은 쾌즈 \\
\hline 47 & & term learning is emphasized over sho & 장기학습을 단기학습보다 강조하고 있다 \\
\hline 48 & & The teaching is too teacher-centred & 수업이 지나치게 교수 중심적이다 \\
\hline 49 & & & 내가 필요한 것을 편안하게 물어볼 수 있다 \\
\hline 50 & & The students irritate the teachers & 학생들이 교수들을 짜증나게 한다 \\
\hline
\end{tabular}


TABLe 2: Overall results of the psychometric test $(N=451)$.

\begin{tabular}{|c|c|c|c|c|c|}
\hline Subscale of DREEM (number of items) & Max & Min & Mean & SD & Number of problematic items \\
\hline SPL (12) & 40 & 2 & 20.08 & 6.76 & 10 \\
\hline SPT (11) & 39 & 2 & 22.12 & 5.97 & 4 \\
\hline SAS (8) & 32 & 1 & 16.74 & 4.59 & 3 \\
\hline SPA (12) & 44 & 3 & 21.53 & 6.03 & 8 \\
\hline SSS (7) & 24 & 1 & 13.60 & 3.48 & 4 \\
\hline Total (50) & 170 & 27 & 94.06 & 22.76 & 29 \\
\hline
\end{tabular}

All data were acquired using a 5-point Likert scale (0-4). DREEM: Dundee Ready Educational Environment Measure. SD: standard deviation. SPL: students' perception of learning; SPT: students' perception of teachers; SAS: students' academic self-perception; SPA: students' perception of atmosphere; SSS: students' social self-perception.

TABLE 3: Subgroup results of the psychometric test $(N=451)$.

\begin{tabular}{|c|c|c|c|c|c|c|c|c|c|}
\hline \multirow[b]{2}{*}{$\begin{array}{l}\text { Subscale (perfect } \\
\text { score) }\end{array}$} & \multicolumn{2}{|c|}{ College } & \multicolumn{2}{|c|}{ Gender } & \multicolumn{5}{|c|}{ School years } \\
\hline & $\begin{array}{c}\mathrm{A} \\
N=218\end{array}$ & $\begin{array}{c}\mathrm{B} \\
N=233\end{array}$ & $\begin{array}{c}\text { Male } \\
N=237\end{array}$ & $\begin{array}{l}\text { Female } \\
N=214\end{array}$ & $\begin{array}{c}2^{\text {nd }} \\
N=86\end{array}$ & $\begin{array}{c}3^{\text {rd }} \\
N=81\end{array}$ & $\begin{array}{c}4^{\text {th }} \\
N=93\end{array}$ & $\begin{array}{c}5^{\text {th }} \\
N=90\end{array}$ & $\begin{array}{c}6^{\text {th }} \\
N=101\end{array}$ \\
\hline SPL (48) & $\begin{array}{l}20.00 \\
(7.09)\end{array}$ & $20.14(6.44)$ & $\begin{array}{l}19.26 \\
(6.99)\end{array}$ & $\begin{array}{l}20.98 \\
(6.39)\end{array}$ & $\begin{array}{l}22.43 \\
(6.47)\end{array}$ & $\begin{array}{l}20.38 \\
(6.82)\end{array}$ & $\begin{array}{l}20.47 \\
(6.68)\end{array}$ & $20.10(6.62$ & $\begin{array}{l}17.44 \\
(6.38)\end{array}$ \\
\hline SPT (44) & $\begin{array}{l}22.78 \\
(6.07)\end{array}$ & $21.50(5.81)$ & $\begin{array}{l}21.34 \\
(6.10)\end{array}$ & $\begin{array}{l}22.99 \\
(5.71)\end{array}$ & $\begin{array}{l}24.10 \\
(5.24)\end{array}$ & $\begin{array}{l}21.09 \\
(6.27)\end{array}$ & $\begin{array}{l}22.65 \\
(5.81)\end{array}$ & $2.41(5.86)$ & $\begin{array}{l}20.52 \\
(6.06)\end{array}$ \\
\hline SAS (32) & $\begin{array}{l}16.88 \\
(4.42)\end{array}$ & $16.61(4.74)$ & $\begin{array}{l}16.41 \\
(4.86)\end{array}$ & $\begin{array}{l}17.11 \\
(4.24)\end{array}$ & $\begin{array}{l}17.65 \\
(4.29)\end{array}$ & $\begin{array}{l}16.09 \\
(5.35)\end{array}$ & $\begin{array}{l}16.63 \\
(4.25)\end{array}$ & $\begin{array}{l}17.49 \\
(4.17)\end{array}$ & $\begin{array}{l}15.91 \\
(4.66)\end{array}$ \\
\hline SPA (48) & $\begin{array}{l}21.58 \\
(6.28)\end{array}$ & $21.48(5.80)$ & $\begin{array}{l}21.13 \\
(5.87)\end{array}$ & $21.97(6.19)$ & $\begin{array}{l}23.60 \\
(5.58)\end{array}$ & $\begin{array}{l}21.26 \\
(6.55)\end{array}$ & $\begin{array}{l}21.43 \\
(5.97)\end{array}$ & $\begin{array}{l}21.46 \\
(6.09)\end{array}$ & $20.13(5.61)$ \\
\hline SSS (28) & $\begin{array}{l}13.54 \\
(3.56)\end{array}$ & $\begin{array}{l}13.66 \\
(3.42)\end{array}$ & $\begin{array}{l}13.46 \\
(3.43)\end{array}$ & $\begin{array}{l}13.76 \\
(3.54)\end{array}$ & $\begin{array}{l}14.37 \\
(3.37)\end{array}$ & $\begin{array}{l}13.30 \\
(4.11)\end{array}$ & $\begin{array}{l}13.18 \\
(3.18)\end{array}$ & $\begin{array}{l}13.43 \\
(3.45)\end{array}$ & $\begin{array}{l}13.72 \\
(3.27)\end{array}$ \\
\hline Total (200) & $\begin{array}{c}94.79 \\
(23.55)\end{array}$ & $\begin{array}{c}93.39 \\
(22.02)\end{array}$ & $\begin{array}{c}91.60 \\
(22.91)\end{array}$ & $\begin{array}{c}96.79 \\
(22.32)\end{array}$ & $\begin{array}{c}102.2 \\
(20.66)\end{array}$ & $\begin{array}{c}92.11 \\
(25.36)\end{array}$ & $\begin{array}{c}94.37 \\
(21.58)\end{array}$ & $\begin{array}{c}94.89 \\
(22.26)\end{array}$ & $\begin{array}{c}87.72 \\
(21.99)\end{array}$ \\
\hline
\end{tabular}

All data were acquired using a 5-point Likert scale (0-4) and expressed as mean values (standard deviation). DREEM: Dundee Ready Educational Environment Measure. N: number of respondents. SPL: students' perception of learning; SPT: students' perception of teachers; SAS: students' academic selfperception; SPA: students' perception of atmosphere; SSS: students' social self-perception.

\section{Discussion}

4.1. The Cross-Cultural Adaptation Process. Cultural and linguistic diversity has caused problems with regard to translation, and many researchers have continued to study translation methods [47]. As a result, a general consensus has been formed for the cross-cultural adaptation process.

Numerous multinational studies have contributed toward DREEM's development. It has been translated into various languages, used in various countries for many years, and has been identified as a nonculturally specific questionnaire [21, 22]. Some studies differed from consensus of cross-cultural adaptation process, such as multiple translators not participating, missing the back translation, or proceeding in a different order [26,48-51]. Some did not elaborate on whether they followed the consensus process or not $[15,24,37,52-56]$.

This study encountered some difficulties because the expert committee found some expressions to be unclear during the process of creating the prefinal version. In response, the final version was produced after a comparison with other questions, agreements between experts, and communication with the original writer (S. Roff). In the cases of item \#12 "timetable," item \#31 "empathy in my profession," and item \#33 "in class socially," it was necessary to accurately define the meaning of the words. "Timetable" can be interpreted in various ways including a syllabus or a class schedule. Roff's response was that it included all such meanings. The meaning of "my professional" in item \#31 also included both doctor-doctor (the ability to form consensuses between doctors, the ability to discuss diagnoses, etc.) and patient-doctor relationships. In the case of item \#33, "class" indicated all courses of study, including lectures and seminars. Internationally, the medical curriculum is not unified, and this can result in differences in terminology. The term "ward teaching" is translated into the Korean term "hoe-jin," which refers to clinical practice conducted by professors, which involves seeing and examining patients in the ward. In Korea, ward teaching is usually conducted in the $6^{\text {th }}$ year of Korean medicine college. In the case of "constructive criticism" in item \#32, students may find the term "constructive" vague. Based on the words and examples provided by Roff, a description that could supplement the word was added in the Korean version. In the case of item \#34, we needed to grasp the meaning of individual "seminars/tutorials." Roff suggested that the word was basically referred to a small number of people and that it was a concept that contrasted with the lectures. Therefore, "seminars/tutorials" was replaced by small group classes/ small group activities in individual practice sessions. 


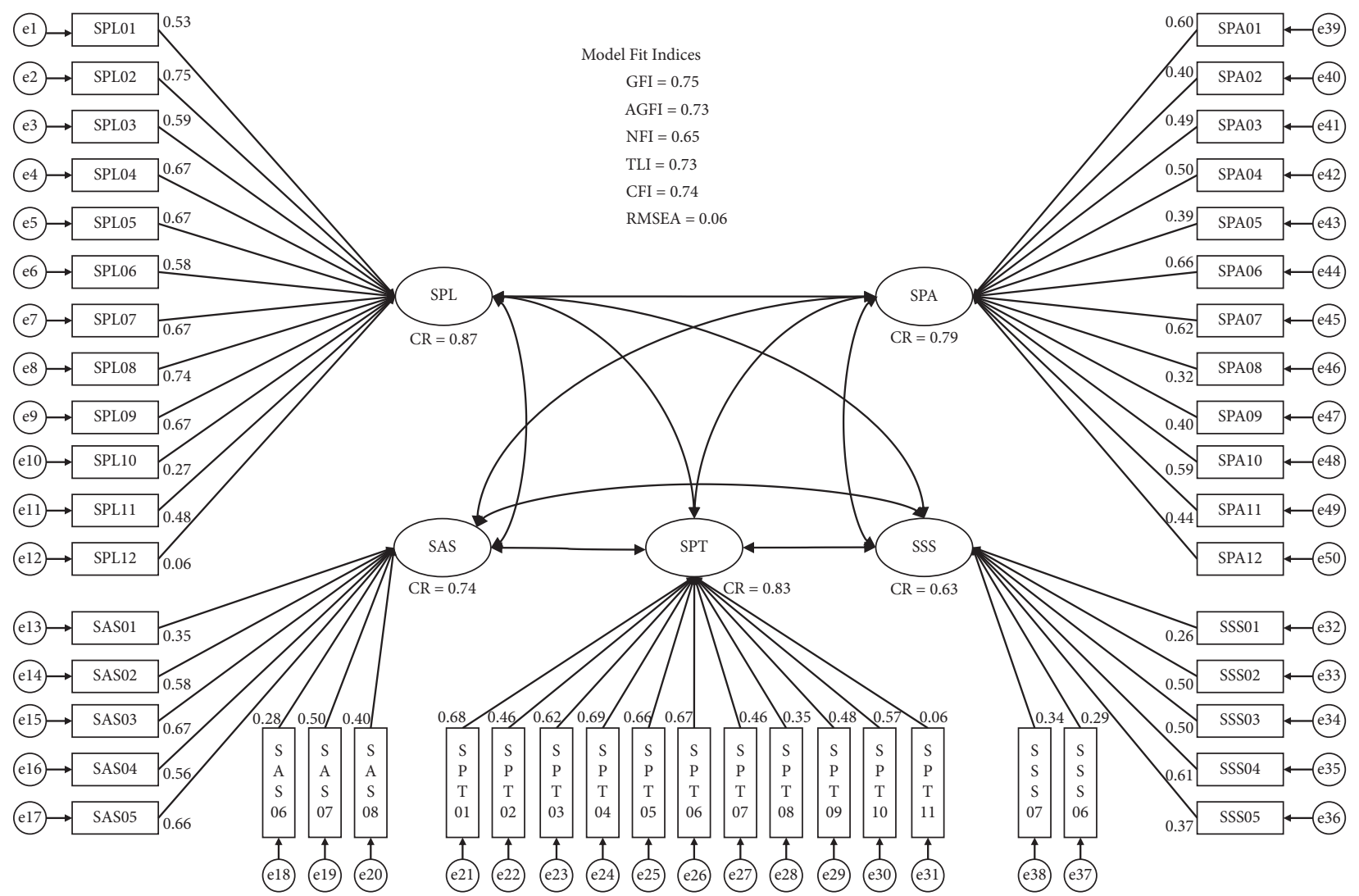

Figure 2: The confirmatory factor analysis model and the model fit indices.

TABle 4: Correlation coefficients, average variances extracted (AVEs), and construct reliabilities (CRs) of subscales for the convergent validity and the discriminant validity.

\begin{tabular}{lccccrr}
\hline & SPL & SPT & SAS & SPA & SSS & AVE \\
\hline SPL & 1 & & & & CR \\
SPT & $0.87(0.76)$ & 1 & & & 0.55 \\
SAS & $0.92(0.85)$ & $0.75(0.56)$ & 1 & 1 & 0.54 & 0.87 \\
SPA & $0.97(0.94)$ & $0.83(0.69)$ & $0.92(0.85)$ & 0.53 & 0.74 \\
SSS & $0.82(0.67)$ & $0.67(0.45)$ & $0.80(0.64)$ & $0.98(0.96)$ & 0.48 \\
\hline
\end{tabular}

The squares of correlation coefficients are expressed in parentheses. SPL: students' perception of learning; SPT: students' perception of teachers; SAS: students' academic self-perception; SPA: students' perception of atmosphere; SSS: students' social self-perception; AVE: average variance extracted; CR: construct reliability.

4.2. Basic Statistics and the Evaluation of Construct Validity. The descriptive statistics of the results showed that many students were not satisfied with the education environments in Korean medicine colleges. The total and subscores of DREEM were almost equal to or less than half score, and $58 \%$ of items were identified as being problematic. This result is similar to that of a previous study in Korea [38]. Thus, education policy on Korean medicine requires further effort and investment.

Next, we examined whether the original 5-factor model of DREEM was suitable for the new dataset obtained from Korean medicine students. We conducted confirmatory factor analysis and calculated several parameters, including goodness-of-fit indices, convergent validity, and discriminant validity.
First, the goodness of fit can be evaluated when the original 5-factor model is applied to the new dataset. Generally, it has been known that RMSEA less than 0.05 is considered to be good, RMSEA between 0.05 and 0.08 is acceptable, RMSEA between 0.08 and 0.1 is marginal, and RMSEA over 0.1 is poor [57]. The RMSEA for our study was 0.06 . We concluded that the original 5-factor model was acceptable for the new dataset obtained from the Korean medicine students. However, the other indices for model fit-GFI, AGFI, NFI, TLI, and CFI-were around 0.7. Among them, TLI and CFI, which were relatively sample size independent, were 0.73 and 0.74 . In other countries, they also had results of about 0.7 [30, 32, 35], respectively, although it is suggested that these indices should be over 0.9 for a good model fit $[58,59]$. Based on these results, we 
concluded that the goodness of fit of this model with our dataset was acceptable but not very good. Such less satisfactory results can imply different concept structures between countries or cultures.

Second, the convergent validity was examined using factor loadings and CRs. Ideally, they must be equal to or greater than 0.707 to demonstrate desirable convergent validity [60-62], but values over 0.5 are also generally accepted [63]. Among 50 items, only 2 items showed factor loading values over 0.707 , and 28 items showed factor loading values over 0.5; however, the CRs of each factor (except for latent variable SSS) were all over 0.707. Based on these indices, we can consider the relatively low convergent validity of the model in this study. Low convergent validity indicates that the items cannot be explained by only the corresponding latent variable and that some other factors are influencing the information of the items. To consider good discriminant validity, the AVE of one factor should be larger than the shared variance estimates with any other factor including measurement errors [64, 65]. In this study, except for the only SPT-SSS pair, all squares of correlation coefficients were greater than the corresponding AVEs. Low convergent validity and low discriminant validity indicated that the original 5-factor model was not suitable for our dataset, which was obtained from Korean medicine students.

This result may have two possible explanations. First, as shown in the basic statistics, many respondents gave low scores across all the items. Such overall low scores may make it difficult to separate the latent variables, and this may induce low construct validity. Second, because of the differences in languages and cultures, the Korean students' perceptions regarding medical education environments may have different structures from the perception of the other countries' students. In order to clarify this issue, further studies with large amounts of samples should be conducted.

4.3. Limitations and Further Research. This study aimed to develop a Korean version of DREEM to promote more active use of DREEM in Korea and to reduce errors in the comparisons of Korean study results and those of other countries. Moreover, we aimed to obtain methodological justification through a strict process of cross-cultural adaptation, not simple translation by a few bilingual translators. Because of differences in terms of languages, cultures, medical systems, and education systems, the meanings of some items had to be modified despite the kind and considerable help of the original developer. We consider this to be an unavoidable aspect of localization that occurs in crosscultural adaptation.

With regard to statistics, the convergence in each factor and the discrimination among factors were not clear. Therefore, our data were not considered to be suitable for the original 5-factor model. As has been suggested by some previous studies, five-factor structure of DREEM (original DREEM subscales) was not good model fit and new structure or abridged version was suggested [24-36]. Through further additional human subject researches in Korea, the structure model can be modified or respecified using consecutive confirmatory factor analysis or exploratory factor analysis.

Therefore, if researches using the Korean version of DREEM, which has undergone cross-cultural translation in this study, are conducted continuously, it could be possible to make policy decisions by analyzing what resource aspects should be put on to improve the quality of medical educational environments through comparison studies between educational institutions and countries. Moreover, it could be possible to objectively evaluate the effect of used resources and improved education systems if data are collected in time series for a specific population.

\section{Conclusion}

In conclusion, we developed the Korean version of DREEM using the guidelines of cross-cultural adaption in order to create an objective evaluation tool for evaluating medical education in Korea. The adaptation process encountered some difficulties; however, we succeeded in finalizing the final Korean version of DREEM with the original author's help and advice. Furthermore, we performed a human subject research and statistical analysis to confirm the construct validity of the translated version. Statistical analysis regarding validity showed that the original 5-factor structure had a somewhat acceptable fit. Nevertheless, with regard to aspects of convergent validity and discriminant validity, low validity indices suggested that further researches should be conducted in Korea in order to study respecified or modified factor structure. If this study's product is used widely in Korea, we expect that the medical educational environment could be improved by identifying and studying the distinct features of the medical education system in Korea.

\section{Data Availability}

The datasets used and/or analyzed during the current study are available from the corresponding author on reasonable request.

\section{Ethical Approval}

Ethical approval was obtained from the Institutional Review Board of Kyung Hee University Korean Medicine Hospital (KOMCIRB-161020-HR-059) regarding the psychometric research included in this study. All participants could only respond to the online survey if they read the written information about the contents of the survey and gave their informed consent online before taking part in the survey.

\section{Consent}

The completion of survey was taken as implied consent.

\section{Disclosure}

Hyunho Kim and Pyeongjin Jeon are the co-first authors. 


\section{Conflicts of Interest}

The authors declare that they have no conflicts of interest.

\section{Authors' Contributions}

HK and PJ designed the whole study, conducted the crosscultural adaptation process, and acquired the questionnaire data. HK and PJ performed data analysis and manuscript preparation. YK conceived the study design, data collection, and manuscript preparation. SK and JH mainly participated in cross-cultural adaptation process and educational discussion. All authors read and approved the final manuscript. Hyunho Kim and Pyeongin Jeon contributed to this paper equally.

\section{Acknowledgments}

The authors thank Susan Roff, the developer of DREEM, for helping in transcultural adaptation and permission to translate DREEM to Korean. The authors appreciate generous support of Institute of Korean Medicine Education and Evaluation (http://www.ikmee.or.kr). The authors also would like to thank Editage (http://www.editage.co.kr) for English language editing. This work was supported by 2020 Research Grant of Wonkwang University.

\section{References}

[1] Association of American Medical Colleges, Report 1 Learning Objectives for Medical Students Education Guidelines for Medical Schools, Association of American Medical Colleges, Washington, DC, USA, 1998.

[2] J. A. Spencer and R. K. Jordan, "Learner centred approaches in medical education," BMJ, vol. 318, no. 7193, pp. 1280-1283, 1999.

[3] P. Salvatori, "Meaningful occupation for occupational therapy students: a student-centred curriculum," Occupational Therapy International, vol. 6, no. 3, pp. 207-223, 1999.

[4] J. M. Genn, "AMEE Medical Education Guide No. 23 (Part 1): curriculum, environment, climate, quality and change in medical education-a unifying perspective," Medical Teacher, vol. 23, no. 4, pp. 337-344, 2001.

[5] D. A. Wiley, The Instructional Use of Learning Objects, Agency for Instructional Technology and Association for Educational Communications \& Technology, Bloomington, IN, USA, 1st edition, 2002.

[6] E. A. AlFaris, N. Naeem, F. Irfan, R. Qureshi, and C. van der Vleuten, "Student centered curricular elements are associated with a healthier educational environment and lower depressive symptoms in medical students," BMC Medical Education, vol. 14, no. 1, 192 pages, 2014.

[7] F. Irfan, E. A. Faris, N. A. Maflehi et al., "The learning environment of four undergraduate health professional schools: lessons learned," Pakistan journal of medical sciences, vol. 35, no. 3, pp. 598-604, 2019.

[8] L. Hutchinson, "ABC of learning and teaching: educational environment," BMJ, vol. 326, no. 7393, pp. 810-812, 2003.

[9] J. M. Genn and R. M. Harden, "What is medical education here really like? suggestions for action research studies of climates of medical education environments," Medical Teacher, vol. 8, no. 2, pp. 111-124, 1986.
[10] A. Lizzio, K. Wilson, and R. Simons, "University students' perceptions of the learning environment and academic outcomes: implications for theory and practice," Studies in Higher Education, vol. 27, no. 1, pp. 27-52, 2002.

[11] H. Till, "Identifying the perceived weaknesses of a new curriculum by means of the dundee ready education environment measure (DREEM) inventory," Medical Teacher, vol. 26, no. 1, pp. 39-45, 2004.

[12] H. Till, "Climate studies: can students' perceptions of the ideal educational environment be of use for institutional planning and resource utilization?" Medical Teacher, vol. 27, no. 4, pp. 332-337, 2005.

[13] D. Soemantri, C. Herrera, and A. Riquelme, "Measuring the educational environment in health professions studies: a systematic review," Medical Teacher, vol. 32, no. 12, pp. 947-952, 2010.

[14] M. Imanipour, A. Sadooghiasl, S. Ghiyasvandian, and H. Haghani, "Evaluating the educational environment of a nursing school by using the DREEM inventory," Global Journal of Health Science, vol. 7, no. 4, pp. 211-216, 2015.

[15] S. M. Caleer, S. Pemba, and S. Roff, "Educational environment, student approaches to learning and academic achievement in a Thai nursing school," Medical Teacher, vol. 22, no. 4, pp. 359-364, 2000.

[16] M. A. Seabrook, "Clinical students' initial reports of the educational climate in a single medical school," Medical Education, vol. 38, no. 6, pp. 659-669, 2004.

[17] S. Roff, "The Dundee Ready Educational Environment Measure (DREEM)-a generic instrument for measuring students' perceptions of undergraduate health professions curricula," Medical Teacher, vol. 27, no. 4, pp. 322-325, 2005.

[18] C. R. Pace and G. G. Stern, "An approach to the measurement of psychological characteristics of college environments," Journal of Educational Psychology, vol. 49, no. 5, pp. 269-277, 1958.

[19] A. M. Fanslow, "Environments in college home economics units as perceived by students," 2895 pages, Iowa State University, Ames, IA, USA, 1966, , Retrospective Theses and Dissertations.

[20] J. W. Menne, "Techniques for evaluating the college Environment1," Journal of Educational Measurement, vol. 4, no. 4, pp. 219-225, 1967.

[21] S. Roff, S. McAleer, R. M. Harden et al., "Development and validation of the dundee ready education environment measure (DREEM)," Medical Teacher, vol. 19, no. 4, pp. 295-299, 1997.

[22] S. Miles, L. Swift, and S. J. Leinster, "The dundee ready education environment measure (DREEM): a review of its adoption and use," Medical Teacher, vol. 34, no. 9, pp. e620-e634, 2012.

[23] C. Y. W. Chan, M. Y. Sum, G. M. Y. Tan, P.-C. Tor, and K. Sim, "Adoption and correlates of the Dundee Ready Educational Environment Measure (DREEM) in the evaluation of undergraduate learning environments-a systematic review," Medical Teacher, vol. 40, no. 12, pp. 1240-1247, 2018.

[24] A. Riquelme, M. Oporto, J. Oporto et al., "Measuring students' perceptions of the educational climate of the new curriculum at the Pontificia Universidad Católica de Chile: performance of the Spanish translation of the Dundee Ready Education Environment Measure (DREEM)," Education and Health, vol. 22, no. 1, 112 pages, 2009.

[25] J. Wang, S. Zang, and T. Shan, "Dundee ready education environment measure: psychometric testing with Chinese 
nursing students," Journal of Advanced Nursing, vol. 65, no. 12, pp. 2701-2709, 2009.

[26] I. D. Dimoliatis, E. Vasilaki, P. Anastassopoulos, J. P. Ioannidis, and S. Roff, "Validation of the Greek translation of the dundee ready education environment measure (DREEM)," Education and Health, vol. 23, no. 1, 348 pages, 2010.

[27] T. Aghamolaei and I. Fazel, "Medical students' perceptions of the educational environment at an Iranian Medical Sciences University," BMC Medical Education, vol. 10, no. 1, 87 pages, 2010.

[28] J. S. Khan, S. Tabasum, U. K. Yousafzai, and M. Fatima, "DREEM on: validation of the dundee ready education environment measure in Pakistan," JPMA. The Journal of the Pakistan Medical Association, vol. 61, pp. 885-8, 2011.

[29] U. Jakobsson, N. Danielsen, and G. Edgren, "Psychometric evaluation of the dundee ready educational environment measure: Swedish version," Medical Teacher, vol. 33, pp. e267-e274, 2011.

[30] M. S. B. Yusoff, "The Dundee ready educational environment measure: a confirmatory factor analysis in a sample of Malaysian medical students," International Journal of $\mathrm{Hu}$ manities and Social Science, vol. 2, pp. 313-321, 2012.

[31] A. E. Kossioni, R. Varela, I. Ekonomu, G. Lyrakos, and I. D. K. Dimoliatis, "Students' perceptions of the educational environment in a Greek dental school, as measured by DREEM: educational environment in athens dental school," European Journal of Dental Education, vol. 16, pp. 73-78, 2012.

[32] S. M. Hammond, M. O’Rourke, M. Kelly, D. Bennett, and S. O'Flynn, "A psychometric appraisal of the DREEM," BMC Medical Education, vol. 12, no. 1, 2 pages, 2012.

[33] M. S. Ostapczuk, A. Hugger, J. De Bruin, S. Ritz-Timme, and T. Rotthoff, "DREEM on, dentists! Students' perceptions of the educational environment in a German dental school as measured by the Dundee Ready Education Environment Measure," European Journal of Dental Education, vol. 16, no. 2, pp. 67-77, 2012.

[34] B. Vaughan, J. Mulcahy, and P. McLaughlin, "The DREEM, part 2: psychometric properties in an osteopathic student population," BMC Medical Education, vol. 14, no. 1, 100 pages, 2014.

[35] V. Mogre and A. Amalba, "Psychometric properties of the Dundee ready educational environment measure in a sample of Ghanaian Medical Students," Education and Health, vol. 29, no. 1, 16 pages, 2016.

[36] K. Jeyashree, H. D. Shewade, and S. Kathirvel, "Development and psychometric testing of an abridged version of dundee ready educational environment measure (DREEM)," Environmental Health and Preventive Medicine, vol. 23, no. 1, 13 pages, 2018.

[37] K. H. Park, J. H. Park, S. Kim et al., "Students' perception of the educational environment of medical schools in Korea: findings from a nationwide survey," Korean Journal of Medical Education, vol. 27, no. 2, pp. 117-130, 2015.

[38] H. Kim, H. Jeong, P. Jeon, S. Kim, Y.-B. Park, and Y. Kang, "Perception study of traditional Korean medical students on the medical education using the dundee ready educational environment measure," Evidence-Based Complementary and Alternative Medicine, vol. 2016, Article ID 6042967, 7 pages, 2016.

[39] F. Guillemin, C. Bombardier, and D. Beaton, "Cross-cultural adaptation of health-related quality of life measures: literature review and proposed guidelines," Journal of Clinical Epidemiology, vol. 46, no. 12, pp. 1417-1432, 1993.

[40] V. D. Sousa and W. Rojjanasrirat, "Translation, adaptation and validation of instruments or scales for use in cross-cultural health care research: a clear and user-friendly guideline," Journal of Evaluation in Clinical Practice, vol. 17, no. 2, pp. 268-274, 2011.

[41] D. E. Beaton, C. Bombardier, F. Guillemin, and M. B. Ferraz, "Guidelines for the process of cross-cultural adaptation of self-report measures," Spine, vol. 25, no. 24, pp. 3186-3191, 2000.

[42] S. McAleer and S. Roff, "A practical guide to using the dundee ready education environment measure (DREEM)," in Curriculum, Environment, Climate, Quality and Change in Medical Education: A Unifying Perspective, J. M. Genn, Ed., vol. 23, pp. 29-33, AMEE Medical Education Guide, Dundee, Scotland, 2001.

[43] R. W. Brislin, "Back-translation for cross-cultural research," Journal of Cross-Cultural Psychology, vol. 1, no. 3, pp. 185-216, 1970.

[44] R. W. Brislin, The Wording and Translation of Research Instruments, pp. 137-164, Field Methods in Cross-Cultural Research, Thousand Oaks, CA, USA, 1986.

[45] J. Harkness, B. E. Pennell, and A. Schoua-Glusberg, Survey Questionnaire Translation and Assessment, pp. 453-473, Wiley Series in Survey Methodology, Hoboken, NJ, USA, 2004.

[46] World Health Organization, "Process of translation and adaptation of instruments," World Health Organization, Geneva, Switzerland, 2016, https://www.who.int/substance_ abuse/research_tools/translation/en/.

[47] W. Maneesriwongul and J. K. Dixon, "Instrument translation process: a methods review," Journal of Advanced Nursing, vol. 48, no. 2, pp. 175-186, 2004.

[48] M. Al-Qahtani, Approaches to Study and Learning Environment in Medical Schools with Special Reference to the Gulf Countries, 525 pages, University of Dundee, Dundee, UK, 1999.

[49] G. Edgren, A. C. Haffling, U. Jakobsson, S. Mcaleer, and N. Danielsen, "Comparing the educational environment (as measured by DREEM) at two different stages of curriculum reform," Medical Teacher, vol. 32, no. 6, pp. e233-e238, 2010.

[50] T. Rotthoff, M. S. Ostapczuk, J. De Bruin, U. Decking, M. Schneider, and S. Ritz-Timme, "Assessing the learning environment of a faculty: psychometric validation of the German version of the Dundee Ready Education Environment Measure with students and teachers," Medical Teacher, vol. 33, no. 11, pp. e624-e636, 2011.

[51] M. Demirören, "Perceptions of students in different phases of medical education of educational environment: ankara university faculty of medicine," Medical Education Online, vol. 13,2008

[52] G. R. de Oliveira Filho, J. E. Vieira, and L. Schonhorst, "Psychometric properties of the dundee ready educational environment measure (DREEM) applied to medical residents," Medical Teacher, vol. 27, no. 4, pp. 343-347, 2005.

[53] Y. Tokuda, E. Goto, J. Otaki et al., "Undergraduate educational environment, perceived preparedness for postgraduate clinical training, and pass rate on the National Medical Licensure Examination in Japan," BMC Medical Education, vol. 10, no. 1, 35 pages, 2010.

[54] N. Lai, S. Nalliah, and R. Jutti, "The educational environment and self- perceived clinical competence of senior medical students in a Malaysian medical school," Education for 
Health: Change in Learning \& Practice, vol. 22, no. 2, 148 pages, 2009.

[55] I. H. Al-Ayed and S. A. Sheik, "Assessment of the educational environment at the college of medicine of King Saud University, Riyadh," Eastern Mediterranean Health Journal, vol. 14, pp. 953-959, 2008.

[56] A. P. O’Brien, T. M. F. Chan, and M. A. A. Cho, "Investigating nursing students' perceptions of the changes in a nursing curriculum by means of the Dundee Ready Education Environment Measure (DREEM) inventory: results of a cluster analysis," International Journal of Nursing Education Scholarship, vol. 5, no. 1, pp. 1-15, 2008.

[57] L. R. Fabrigar, D. T. Wegener, R. C. MacCallum, and E. J. Strahan, "Evaluating the use of exploratory factor analysis in psychological research," Psychological Methods, vol. 4, no. 3, pp. 272-299, 1999.

[58] S. A. Mulaik, L. R. James, J. Van Alstine, N. Bennett, S. Lind, and C. D. Stilwell, "Evaluation of goodness-of-fit indices for structural equation models," Psychological Bulletin, vol. 105, no. 3, pp. 430-445, 1989.

[59] P. M. Bentler, "Comparative fit indexes in structural models," Psychological Bulletin, vol. 107, no. 2, pp. 238-246, 1990.

[60] F. H. Joseph, C. B. William, J. B. Barry, and E. A. Rolph, Multivariate Data Analysis with Readings, Prentice-Hall, Upper Saddle River, NJ, USA, 5th edition, 1998.

[61] C. Fornell, G. Tellis, and G. Zinkhan, "Validity assessment: a structural equations approach using partial least squares," in Proceedings of the American Marketing Association Educators' Conference, pp. 1-5, Chicago, IL, USA, March 1982.

[62] J. C. Anderson and D. W. Gerbing, "Structural equation modeling in practice: a review and recommended two-step approach," Psychological Bulletin, vol. 103, no. 3, pp. 411-423, 1988.

[63] R. P. Bagozzi and Y. Yi, "On the evaluation of structural equation models," Journal of the Academy of Marketing Science, vol. 16, no. 1, pp. 74-94, 1988.

[64] C. Fornell and D. F. Larcker, "Evaluating structural equation models with unobservable variables and measurement error," Journal of Marketing Research, vol. 18, no. 1, pp. 39-50, 1981.

[65] A. M. Farrell, "Insufficient discriminant validity: a comment on bove, pervan, beatty, and shiu (2009)," Journal of Business Research, vol. 63, no. 3, pp. 324-327, 2010. 